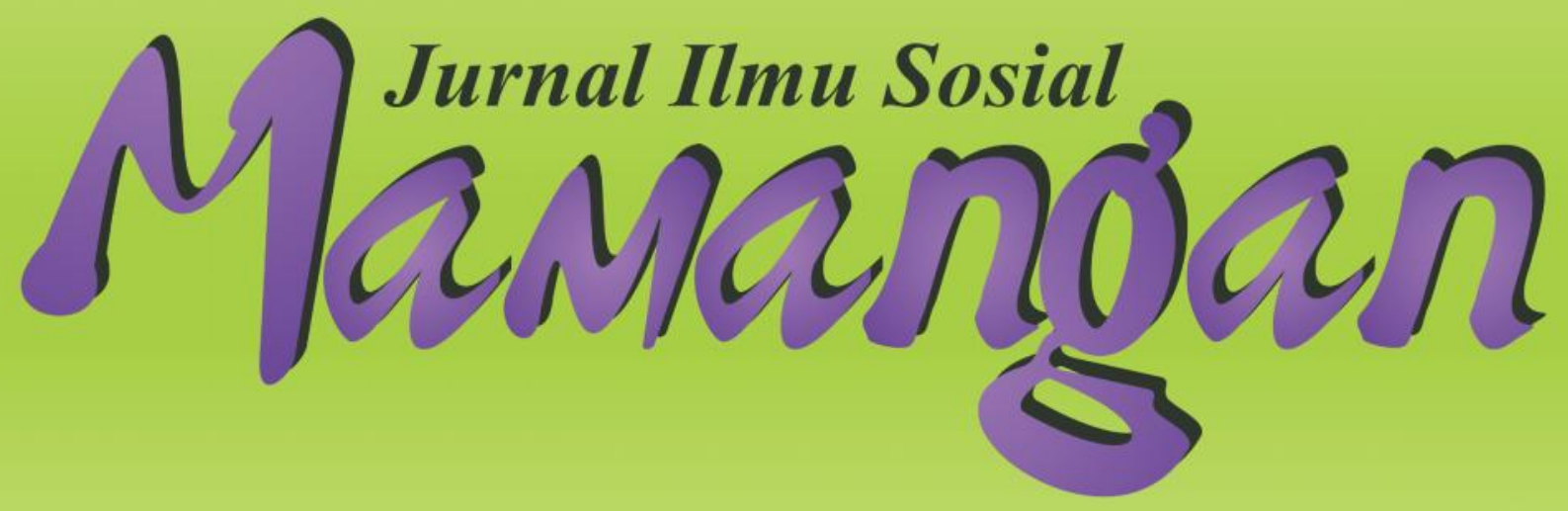

Efektifitas Program Keluarga Harapan (PKH) Dalam Upaya Pengentasan Kemiskinan Di Nagari Lagan Hilir, Kab. Pesisir selatan Apando Ekardo, Firdaus \& Nilda Elfemi

Pelaksanaan Program Corporate Social Responsibility (CSR) PT. VUM (Visi Utama Mandiri)

Yesi Herlina, Dian Anggraini Oktavia \& Elvawati

Sosial Ekonomi Perempuan Migran Kembali (Return Migrant) Jorong Kapuh, Nagari Sumani, Kab. Solok

Yuliana Nengrum, Yulkardi, Darmairal Rahmad

Pengemis Anak Di Pasar Raya Padang, Sumatera Barat

Mira Dona Eka Putri, Yulkardi \& Nilda Elfemi

Buruh Tani Jemputan Di Desa Sako Dua, Kec. Kayu Aro Barat, Kab. Kerinci

Wibi Wijaya, Zusmelia \& Elvawati

Konflik Pengelolaan Parkir Liar Di Pantai Purus, Kec. Padang Barat, Kota Padang

IImiati Amril, Ardi Abbas \& Surya Prahara 


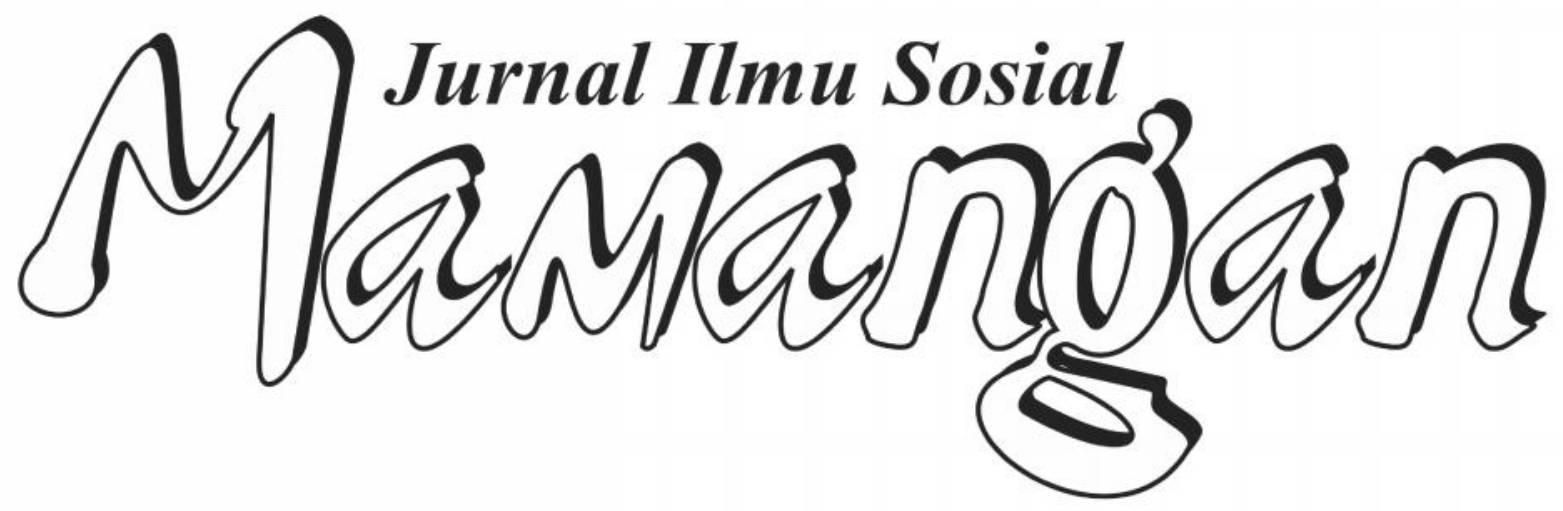




\section{Mitra Bestari}

Prof. Dr. Afrizal, MA. (FISIP, Unand Padang)

Dr. A. Latief Wiyata, M. Si. (Universitas Jember, Jember)

Prof. Dr. Badaruddin, M. Si. (FISIP, USU Medan)

Dr. Fikarwin Zuska, M. Si. (FISIP, USU Medan)

Nurus Shalihin, M. Si., Ph.D. (Fak. Ushuluddin IAIN Imam Bonjol Padang)

Dr. Semiarto A. Purwanto, M. Si. (FISIP, UI Jakarta)

Dr. Wahyu Wibowo, M. Si. (Universitas Nasional, Jakarta)

\section{Dewan Redaksi}

Dr. Zusmelia, M. Si.

Dr. Maihasni, M. Si.

Firdaus, S. Sos., M. Si.

\section{Pemimpin Redaksi}

Firdaus, S. Sos., M. Si.

\section{Anggota Redaksi}

Dian Kurnia Anggreta, S. Sos., M. Si.

Rinel Fitlayeni, S. Sos., MA.

Rio Tutri, M.Si.

Sri Rahayu, M. Pd.

Surya Prahara, SH.

Yuhelna, MA

ISSN: 2301-8496

Alamat Redaksi:

Laboratorium Program Studi Pendidikan Sosiologi, STKIP PGRI Sumbar Kampus STKIP PGRI, Jl. Gunung Pangilun, Padang, Sumatera Barat

Email: redaksimamangan@yahoo.com \& daus_gila @yahoo.com

Penerbit :

Program Studi Pendidikan Sosiologi, STKIP PGRI Padang 


\section{DAFTAR ISI}

Efektifitas Program Keluarga Harapan (PKH) Dalam Upaya Pengentasan Kemiskinan Di Nagari Lagan Hilir, Kab. Pesisir selatan

Apando Ekardo, Firdaus \& Nilda Elfemi ..

Pelaksanaan Program Corporate Social Responsibility (CSR) PT. VUM

Yesi Herlina, Dian Anggraini Oktavia \& Elvawati

Sosial Ekonomi Perempuan Migran Kembali (Return Migrant) Jorong Kapuh, Nagari Sumani, Kab. Solok

Yuliana Nengrum, Yulkardi, Darmairal Rahmad

Pengemis Anak Di Pasar Raya Padang, Sumatera Barat

Mira Dona Eka Putri, Yulkardi \& Nilda Elfemi

Buruh Tani Jemputan Di Desa Sako Dua, Kec. Kayu Aro Barat, Kab. Kerinci

Wibi Wijaya, Zusmelia \& Elvawati.

Konflik Pengelolaan Parkir Liar Di Pantai Purus, Kec. Padang Barat, Kota Padang

Ilmiati Amril, Ardi Abbas \& Surya Prahara

$40-48$ 


\title{
EFEKTIFITAS PROGRAM KELUARGA HARAPAN (PKH) DALAM UPAYA PENGENTASAN KEMISKINAN DI NAGARI LAGAN HILIR, KAB. PESISIR SELATAN
}

\author{
Apando Ekardo, Firdaus \& Nilda Elfemi \\ Sekolah Tinggi Keguruan dan Ilmu Pendidikan (STKIP) PGRI Sumatera Barat
}

\begin{abstract}
Poverty is a multidimensional problem. Characteristic poverty is low average quality of life of the population, education, health, child nutrition, and sources of drinking water. Various attempts have been made by the Indonesian government to alleviate poverty. Once of the program is Program Keluarga Harapan (PKH). This research is to describe effectiveness of the PKH in poverty reduction efforts in Nagari Lagan Hilir Punggasan. The objectives of this study is to describe the effectiveness of the PKH for poor households. The study conducted with qualitative by descriptive type. Informants selected with purposive. Data collected through observation, interview and study document. Result is PKH in Nagari Lagan Hilir Punggasan has been effective base on program objectives. On the other hand, the targeting of PKH beneficiaries for households in Nagari Lagan Hilir Punggasan is not effective. This is due to the targeting of PKH in Nagari Lagan Hilir Punggasan still not on target..
\end{abstract}

\section{Keywords : Poverty, Program Keluarga Harapan, Effectivenes .}

\begin{abstract}
ABSTRAK
Kemiskinan merupakan masalah multidimensi yang ditandai oleh rendahnya rata-rata kualitas hidup penduduk, pendidikan, kesehatan, gizi anak-anak, dan sumber air minum. Berbagai upaya telah dilakukan oleh pemerintah Indonesia untuk mengentaskan kemiskinan. Salah satunya adalah Program Keluarga Harapan (PKH). Penelitian ini bertujaun untuk mendeskripsikan efektivitas Program Keluarga Harapan (PKH) dalam upaya pengentasan kemiskinan di Nagari Lagan Hilir Punggasan. Tujuan yang ingin dicapai dalam penelitian ini adalah mendeskripsikan efektivitas PKH bagi rumah tangga miskin. Penelitian dilakukan dengan kualitatif tipe deskriptif. Informan dipilih secara purposive. Data dikumpulkan melalui observasi, wawancara, dan studi dokumen. Hasil penelitian menunjukkan bahwa program PKH di Nagari Lagan Hilir Punggasan sudah efektif jika dilihat dari tujuan program. Namun di sisi lain penetapan sasaran penerima bantuan PKH bagi RTSM di Nagari Lagan Hilir Punggasan belum bisa dikatakan efektif penentuan sasaran belum tepat sasaran
\end{abstract}

Keywords : Kemiskinan, Program Keluarga Harapan, Efektifitas

\section{PENDAHULUAN}

Kemiskinan merupakan masalah multidimensi yang ditandai oleh rendahnya rata-rata kualitas hidup penduduk, pendidikan, kesehatan, gizi anak-anak, dan sumber air minum. Beban kemiskinan sangat dirasakan oleh kelompok-kelompok tertentu seperti perempuan dan anak-anak yang berakibat pada terancamnya masa 
depan oleh karena kekurangan gizi, dan rendahnya tingkat kesehatan dan pendidikan (Simanjuntak, 2010). Kemiskinan merupakan masalah multidimensi yang didefinisikan sebagai kondisi dimana seseorang atau sekelompok orang yang tidak terpenuhi hak-hak dasarnya untuk mempertahankan dan mengembangkan kehidupan yang bermartabat (Dirjen PMD Depdagri, 2003) dalam (Parnamian, 2010).

Berbagai upaya telah dilakukan oleh pemerintah Indonesia dalam menanggulangi kemiskinan. Upaya tersebut dilakukan untuk memberikan peluang kepada masyarakat miskin untuk meningkatkan kesejahteraan hidupnya. Upaya-upaya menanggulangi kemiskinan sampai saat ini masih dinilai belum berjalan sesuai dengan yang diharapkan. Jumlah golongan miskin bukannya berkurang, akan tetapi semakin besar dan bertambah. Kabupaten Pesisir Selatan, angka kemiskinan dalam tiga tahun terakhir terus mengalami peningkatan. Berbagai upaya telah dilakukan oleh pemerintah Indonesia untuk mengentaskan kemiskinan tersebut. Upaya-upaya penanggulangan kemiskinan di Indonesia diantaranya adalah Jaring Pengaman Sosial (JPS), Subsidi Langsung Tunai (SLT), Beras Miskin (Raskin), Asuransi Kesehatan untuk Masyarakat Miskin (Askeskin), Bantuan Operasional Sekolah (BOS), Program Nasional Pemberdayaan Masyarakat Mandiri (PNPM), serta program yang terakhir diluncurkan adalah Program Keluarga Harapan (PKH)(Simanjuntak, 2010).

Program Keluarga Harapan (PKH) merupakan salah satu diantara program-program penanggulangan kemiskinan tahun 2007 yang dicanangkan oleh pemerintah. Sasaran atau penerima bantuan $\mathrm{PKH}$ adalah Rumah Tangga Sangat Miskin (RTSM) yang memiliki anggota keluarga yang terdiri dari anak usia 0-15 tahun dan/atau ibu hamil/nifas dan berada pada lokasi terpilih. Tujuan utama dari PKH adalah untuk mengurangi kemiskinan dan meningkatkan kualitas sumber daya manusia terutama pada kelompok masyarakat miskin. Dalam jangka pendek, bantuan ini membantu mengurangi beban pengeluaran RTSM, sedangkan untuk jangka panjang, dengan mensyaratkan keluarga penerima untuk menyekolahkan anaknya, melakukan imunisasi balita, memeriksakan kandungan bagi ibu hamil, dan perbaikan gizi, diharapkan akan memutus rantai kemiskinan antar generasi.

Di Kabupaten Pesisir Selatan PKH telah dilakukan sejak tahun 2007, namun hanya 2 Kecamatan yang mendapat bantuan PKH yakni Kecamatan Linggo Sari Baganti dan Kecamatan Lunang Silaut. Di Kecamatan Lunang Silaut yang mendapat bantuan PKH hanya berjumlah 1.251 RTSM sedangkan di Kecamatan Linggo Sari Baganti lebih banyak mendapat bantuan PKH berjumlah 2.393 RTSM dan termasuk di dalamnya Nagari Lagan Hilir Punggasan. PKH di Nagari Lagan Hilir Punggasan di tahun 2007, mulai dilaksanakan dengan jumlah penerima 74 RTSM, bantuan diberikan 4 tahap per tahun (per 3 bulan). Hingga saat ini PKH telah berjalan 5 tahun lebih. Penelitian ini lebih memfokuskan kajian pada faktor dari dalam individu yaitu dari rumah tangga miskin penerima dana bantuan PKH dalam pemanfaatan dana bantuan tersebut. Tujuan yang ingin dicapai dalam penelitian ini adalah mendeskripsikan efektivitas Program Keluarga Harapan (PKH) bagi rumah tangga miskin.

\section{TINJAUAN PUSTAKA}

Penelitian sebelumnya yang berhubungan dengan program penanggulangan kemiskinan, telah dilakukan pertama oleh Gusnaidi pada 
tahun 1998. Penelitian mengenai Kendala Pemberdayaan Masyarakat Miskin melalui Program Inpres Desa Tertinggal (IDT). Kasus pelaksanaan Program IDT Tahap I (Tahun Anggaran 1994/1995) di Desa Aur Begalung Kecamatan Bayang Kabupaten Pesisir Selatan. Dari hasil penelitiannya diketahui bahwa, faktor-faktor yang menjadi kendala pemberdayaan masyarakat miskin melalui program IDT adalah tidak berfungsinya agen-agen sosialisasi secara ideal, kemudian tidak efektifnya komunikasi antara pendamping dengan anggota Pokmas (Para Tokoh Masyarakat) sehingga komunikasi yang harmonis tidak tercapai. Dan juga hal lain yang menjadi kendala adalah peran anggota Pokmas yang sebagai objek. Artinya masyarakat miskin memposisikan dirinya dengan title selalu berada di bawah dan hanya sekedar menerima program (Gusnaidi, 1998).

Hasil penelitian Hastuti pada tahun 2006 mengenai Kajian Cepat Pelaksanaan Subsidi Lansung Tunai Tahun 2005 di Indonesia, studi kasus di lima Kabupaten/Kota. Hasil kajian memperlihatkan bahwa terbatasnya waktu yang disediakan untuk setiap tahapan program subsidi langsung tunai mulai dari proses penargetan, sosialisasi, pendistribusian kartu, pencairan dana hingga penangganan masalah, membuat pelaksanaanya terkesan dipaksakan dan ketergesaannya berpengaruh terhadap keberhasilan pelaksanaan masingmasing tahap tersebut. Sosialisasi program merupakan tahap yang dinilai paling lemah karena tidak dilakukan secara intensif dan tidak didukung instrumen yang memadai. Penanganan masalah juga dinilai masih lemah, terutama menyangkut kelembagaan di tingkat lokal yang belum dibentuk, secara umum tahapan pelaksanaan program lainnya relatif berlangsung lebih baik, namun adanya kesalahan penargetan memicu konflik dan kecemburuan sosial (Hastuti, 2006).

Penelitian lain yang dilakukan oleh Melistin Anggraini pada tahun 2008, dengan judul, "Perilaku Anggota Rumah Tangga Miskin Dalam Memanfaatkan Bantuan Langsung Tunai Program Kompensasi Pengurangan SubsidiBahan Bakar Minyak (BLT-PKPS-BBM) di Kelurahan Banuaran Kecamatan Lubuk Bagaluang Kota Padang”. Penelitian ini mengungkapkan tentang perilaku rumah tangga miskin yang menerima BLT-PKPS-BBM tidak dapat memanfaatkan dana yang didapatkannya dengan sebaik mungkin, misalnya digunakan untuk mabukmabukan, berjudi dan membeli kebutuhan-kebutuhan pokok, sehingga walaupun harga tersebut semakin mahal rumah tanggga miskin masih dapat membelinya dengan menggunakan dana bantuan yang diterimanya. Ia mengungkapakan perilaku rumah tangga miskin disana adalah perilaku konsumtif, mempunyai etos kerja yang lemah (Anggraini, 2008). Penelitian ini juga membahas tentang program pengentasan kemiskinan. Namun pembahasan menitikberatkan perhatian pada efektivitas PKH dalam pengentasan kemiskinan di Nagari Lagan Hilir Punggasan Kec. Linggo Sari Baganti Kab. Pesisir Selatan.

\section{METODE PENELITIAN}

Penelitian ini dilaksanakan di Nagari Lagan Hilir Punggasan, Kecamatan Linggo Sari Baganti Kabupaten Pesisir Selatan pada bulan Maret-April 2014. Penelitian menggunakan pendekatan kualitatif, prosedur penelitian yang menghasilkan data deskriptif berupa kata-kata tulisan atau lisan dari orang-orang dan prilaku yang dapat diamati, tipe penelitian ini deskriptif yang menggambarkan berbagai kondisi dan sesuatu hal seperti apa adanya. Jenis data yang digunakan yaitu data primer dan data skunder. 
Teknik pengumpulan data adalah observasi, wawancara, dan studi dokumen.

\section{PELAKSANAAN PKH DI NAGARI LAGAN HILIR PUNGGASAN}

Kemiskinan di Nagari Lagan Hilir Punggasan terbagi menjadi dua ketegori, pertama rumah tangga sangat miskin yang tergolong masyarakat yang bekerja sebagai buruh tani dan tidak mempunyai perkerjaan tetap dengan persentase $4.12 \%$ dari jumlah penduduk, dan kedua rumah tangga miskin yang tergolong bekerja sebagai petani dan berkebun dengan persentase $33.15 \%$ dari jumlah penduduk. Sedangkan jumlah masyarakat miskin di Nagari Lagan Hilir Punggasan adalah 150 RTSM.

Di Nagari Lagan Hilir Punggasan data penerima $\mathrm{PKH}$ terbagi menjadi dua kelompok, kelompok pertama berjumlah 34 RTSM yang berada di Kampung Bukit Putus Luar, dan kelompok yang kedua berjumlah 40 RTSM yang berada di Kampung Lagan Gadang Hilir, jadi di Nagari Lagan Hilir Punggasan yang mendapat bantuan Program Keluarga Harapan berjumlah 74 RTSM.

Diketahui bahwa dalam pendataan RTSM yang mendata hanya Wali kampung dan kader-kadernya, dalam menentukan siapa yang berhak untuk menedapatkan bantuan PKH hanya melihat bagaimana hubungan kader yang mendata dengan orang yang didata, kalau ada hubungan kekeluargaan maka ia bisa diusulkan sebagai calon penerima bantuan PKH. Disini terlihat pendataan penerima bantuaan Program Keluarga Harapan tidak efektif, karena ada kejanggalankejanggalan yang tidak sesuai dengan kriteria umum Program Keluarga Harapan (PKH).

Dalam prosedur penerimaan dana bantuan $\mathrm{PKH}$, pendamping $\mathrm{PKH}$ memberikan informasi kepada ketua kelompok, dan ketua kelompok bertugas untuk memberi tahu anggota lainnya. Jadwal dan pelaksanaan penyaluran bantuan disesuaikan dengan situasi dan kondisi yang ada pada tahun berjalan serta disesuaikan dengan kebijakan yang dibuat untuk memperlancar pelaksanaan penyaluran bantuan. Dalam prosedur pencairan dana bantuan $\mathrm{PKH}$, para peserta tidak ada sama sekali mendapat undangan yang bersifat pemberitahuan tentang kapan jadwal pencairan dana bantuan tersebut. Diketahui bahwa dalam prosedur penerimaan dana bantuan pendamping hanya memberikan informasi melalui kelompok PKH, tidak adanya surat edaran yang diberikan kepada anggota PKH berakibat pada informasi yang diberikan dari mulut ke mulut tidak efektif untuk kelancaran sebuah program. Karena informasi dari mulut ke mulut bisa saja berubah dari orang ke orang, ini akan membuat anggota PKH menjadi bingung dan ragu dalam menerima informasi tersebut. Sudah lima tahun lebih program PKH berjalan di Nagari Lagan Hilir seharusnya pendamping menetapkan jadwal kapan dan dimana akan dilaksanakan pertemuan dengan peserta $\mathrm{PKH}$, sehingga peserta $\mathrm{PKH}$ tidak bingung kapan dana bantuan akan dicairkan.

Jumlah dana yang diterima oleh peserta PKH tidak menentu, ini dikarenakan bahwa tanggungan setiap keluarga itu berbeda-beda maka dari itu jumlah bantuan yang diterima juga berbeda juga, dengan adanya perbedaan komposisi anggota keluarga peserta $\mathrm{PKH}$, maka besar bantuan yang diterima akan bervariasi pada setiap tahapan bantuan. Jumlah dana yang diterima oleh RTSM tidak mencukupi kebutuhan mereka, namun mereka tetap bersyukur karena telah mendapat bantuan dari pemerintah dan juga mereka mengatakan bahwa bantuan yang diberikan telah membantu dalam biaya pendidikan dan dibidang kesehatan 
walaupun tidak mencukupi untuk keperluan sehari-hari, dan mereka berharap kepada pemerintah untuk lebih meningkatkan jumlah bantuan yang diberikan supaya uang yang mereka dapat bisa berguna untuk biaya pendidikan dan untuk membeli makanan yang bergizi untuk anakanaknya.

Penerima bantuan dalam memanfaatkan bantuan tersebut digunakan untuk membeli pakaian anak dan kebutuhan lainnya. Dana bantuan PKH bagi peserta PKH tidaklah memenuhi kebutuhan bagi keluarga RTSM. Dana bantuan tersebut hanya dapat membantu sebahagian dari biaya keperluan pendidikan anaknya, akan tetapi tidak cukup untuk memenuhi kebutuhan keluarga, khususnya biaya pendidikan dan gizi bayi bagi anak-anak RTSM.

Mereka mengangap bahwasanya perlengkapan pendidikan anak-anaknya semuanya mahal dan tidak mencukupi dengan bantuan yang mereka terima, uang yang mereka hanya sedikit sedangkan kebutuhan dan perlengkapan yang akan dibeli mahal. Disini juga terlihat bahwasanya masyarakat hanya berharap pada bantuan pemerintah dan tidak adanya semangat kerja untuk merubah nasibnya sendiri. Paradigma seperti yang dijelaskan di atas menjadikan RTSM malas, cenderung pasrah pada keadaan yang ada dan susah memotivasi diri untuk mau lepas dari kemiskinan, hal ini memiliki korelasi dengan apa yang disebut dengan dengan budaya kemiskinan yang dijelaskan oleh Oscar Lewis (Suparlan, 1984).

Oscar Lewis menjelaskan dimana budaya kemiskinan mencakup pada apa yang diyakini (nilai-nilai), respon dalam tindakan (sikap) dan abtraksi-abtraksi dari kelakuan sehingga terbentuk sikap ketergantungan, kuatnya perasaan tidak berharga dan memiliki sikap rendah diri. Teori yang dikemukan oleh Oscar Lewis ini juga ditegaskan oleh Weber. Weber menyatakan bahwa kemiskinan bermula dari karakteristik orang miskin itu sendiri.
Orang miskin karena tidak mau bekerja keras, boros, tidak mempunyaai rencana, kurang memiliki jiwa wiraswata, fatalistic, dan tidak ada hasrat untuk berprestasi. Orang miskin karena memiliki budaya kemiskinan yang mencakup karakteristik, psikologis, sosial dan ekonomi. Pandangan konservatif memandang dan melihat bahwa program-program pemerintah mengubah sikap mental masyarakat miskin merupakan usaha yang sia-sia karena akan memancing manipulasi kenaikan jumlah kaum miskin yang ingin menikmati program pemerintah (Suharto, 1995:140 dalam (Anggraini, 2008).

\section{EFEKTIVITAS PKH}

\section{Bidang Kesehatan}

Bahwa masyarakat miskin yang dahulunya tidak mau membawa anaknya berobat ke Puskesmas, namun sekarang pada umumnya semua masyarakat miskin sudah berobat ke Puskesmas, karena setiap masyarakat miskin yang berobat ke Puskesmas tidak dikenakan biaya, karena dibiayai Program Keluarga Harapan. Sejak adanya Program Keluarga Harapan di Nagari Lagan Hilir Punggasan kujungan masyarakat miskin untuk membawa anaknya yandu ke Puskesmas rutin dilakukan. Hal tersebut menunjukkan bahwa tujuan dari PKH bidang kesehatan sudah terealisasi dengan baik, walaupun masih ada sebagian masyarakat memperhitungkan biaya transportasi untuk pergi berobat ke Puskesmas.

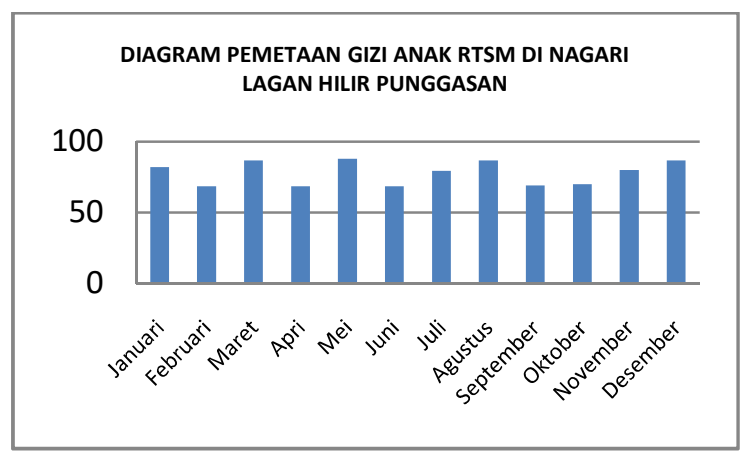

Sumber: Puskesmas Air Haji Kec. Linggo Sari Baganti (2013) 
Berdasarkan diagram di atas terlihat bahwa pada bulan Januari peningkatan gizi bayi adalah $82.2 \%$, sedangkan pada bulan Februari 68.7 \%, pada bulan Maret $86.9 \%$, pada bulan April $68.7 \%$, pada bulan Mei $88.0 \%$, pada bulan Juni $68.7 \%$, pada bulan Juli $79.6 \%$, pada bulan Agustus $86.9 \%$, pada bulan September $69.3 \%$, pada bulan Oktober $70.2 \%$, pada bulan November $80.0 \%$, pada bulan desember $86.9 \%$. Berdasarkan uraian di atas dapat dilihat bahwa pada tahun 2013 gizi bayi di Nagari Lagan Hilir Punggasan dari bulan ke bulan selalu mengalami perubahan, dan jika pada tahun 2013 target gizi bayi paling rendah per bulannya adalah $70 \%$, dan jika dilihat dari tabel di atas yang berada dibawah target hanya 4 bulan dan selebihnya berada di atas target. Jadi dapat disimpulkan bahwa pada tahun 2013 gizi bayi di Nagari Lagan Hilir Punggasan selalu mengalami peningkatan, hanya $40 \%$ penurunan gizi dan $60 \%$ selalu meningkat dalam satu tahun. Hal tersebut menunjukkan bahwa tujuan dari PKH di bidang kesehatan sudah terealisasi dengan baik.

\section{Bidang Pendidikan}

Minat anak-anak sudah meningkat ini terlihat dari tingkat kehadirannya, ini dukung oleh Program- Program pemerintah seperti wajib sekolah 9 tahun dan Bantuan Operasional Sekolah dan beasiwa untuk anakanak yang kurang mampu dan terakhir program pemerintah yang keluarkan untuk mendukung pendidikan bagi anak yang kurang mampu adalah Program Keluarga yang bertujuan untuk meningkatkan taraf pendidikan anak RTSM.

Program ini memberikan bantuan dana untuk meringankan beban RTSM dalam menyekolahkan anakanaknya, dana tersebut digunakan oleh RTSM untuk membeli keperluan perlengkapan sekolah anak- anaknya, seperti; Pakaian, LKS, dan buku tulis yang diperlukan, sehingga bisa menunjang minat anak-anak untuk sekolah. Hal tersebut menunjukkan bahwa tujuan dari PKH di bidang pendidikan sudah terealisasi dengan baik. Hal ini dilihat dari tingkat kehadiran murid di sekolah.

\section{KELEMAHAN-KELEMAHAN PKH DI NAGARI LAGAN HILIR PUNGGASAN}

\section{Tidak Tepat Sasaran}

Di Nagari Lagan Hilir Punggasan Program Keluarga Harapan masih ada diberikan kepada masyarakat yang dikategorikan menegah keatas. Masih ada masyarakat kurang mampu dan lebih membutuhkan bantuan tersebut yang tidak mendapatkan, dan juga dalam pendataan RTSM yang mendata hanya Wali Kampung dan kaderkadernya. Akibatnya adalah dalam menentukan siapa yang berhak untuk mendapatkan bantuan PKH hanya melihat bagaimana hubungan kader yang mendata dengan orang yang di data, kalau ada hubungan kekeluargaan maka ia bisa diusulkan sebagai calon penerima bantuan PKH.

\section{Tidak Mencover Semua Orang Miskin}

Berdasarkan hasil penelitian di lapangan diketahui bahwa jumlah orang miskin di Nagari Lagan hilir punggasan berjumlah 150 RTSM, sedangkan jumlah masyarakat miskin yang mendapat bantuan program keluarga harapan hanya 74 orang. Jadi masih ada 76 RTSM miskin yang belum mendapat bantuan program keluarga harapan. Tidak semua orang miskin yang mendapat bantuan Program Keluarga Harapan, ini dikarenakan Program Keluarga harapan diutamakan bagi rumah tangga sangat miskin (RTSM) yang 
memiliki ibu hamil/menyusui, dan anak usia 0-15 tahun, atau anak usia 15-18 tahun yang belum menyelesaikan pendidikan dasarnya. Sehingga disini dapat dilihat bahwa Program Keluarga Harapan tidak mencakup semua orang miskin.

\section{Koordinasi Pendamping \& Pemerintah Lokal Lemah}

Berdasarkan hasil penelitian menunjukkan bahwa mereka selaku pemerintah Nagari tidak begitu mengetahui tentang bantuan $\mathrm{PKH}$, mereka mengatakan bahwasanya, mereka kurang ikut serta dalam Program Keluarga Harapan karena tidak mendapat undangan ketika Pedamping $\mathrm{PKH}$ mengadakan pertemuan, mereka hanya mendapat data dari pendamping. Data yang diberikan adalah nama-nama RTSM yang mendapat bantuan PKH.

Kurangnya komunikasi antara pendamping $\mathrm{PKH}$ dengan pemerintah nagari setempat membuat tidak hubungan yang tidak baik antara pendamping dengan pemerintah Nagari setempat. Seharusnya antara pendamping dengan pemerintah nagari setempat selalu menjalin komunikasi yang baik dengan cara melakukan pertemuan, pendamping hendaknya mengundang Wali Nagari dengan Wali Kampung setiap ada pertemuan dengan peserta $\mathrm{PKH}$, sehingga pemerintah nagari tahu dan juga dapat memberikan dukungan terhadap RTSM untuk lebih baik dalam memanfaatkan dana bantuan tersebut.

Namun kurangnya koordinasi pendamping dengan pemerintah Nagari setempat yang mana hasil penelitian menunjukkan pemerintah Nagari tidak tahu tentang Program Keluarga Harapan, padahal pemerintah Nagari ikut bertanggung jawab terhadap program baik dalam kesuksesan program maupun kendala yang terjadi dilapangan dan pemerintah Nagari termasuk dalam Unit pelaksanaan $\mathrm{PKH}$, yang merupakan kunci untuk kesuksesan pelaksanaan $\mathrm{PKH}$.

\section{Minim Sosialisasi Pencairan Dana Bantuan}

Berdasarkan hasil penelitian di lapangan terlihat bahwa Jadwal dan pelaksanaan penyaluran bantuan disesuaikan dengan situasi dan kondisi yang ada pada tahun berjalan serta disesuaikan dengan kebijakan yang dibuat untuk memperlancar pelaksanaan penyaluran bantuan. Dalam prosedur pencairan dana bantuan PKH, para peserta tidak ada sama sekali mendapat undangan yang bersifat pemberitahuan tentang kapan jadwal pencairan dana bantuan tersebut, pendamping $\mathrm{PKH}$ hanya memberikan informasi melalui ketua PKH.

Pada prosedur penerimaan uang bantuan pendamping hanya memberikan informasi melalui ketua kelompok PKH, tidak adanya surat edaran yang diberikan kepada anggota PKH. Informasi yang diberikan dari mulut ke mulut ini tidak efektif untuk kelancaran sebuah program, karena informasi dari mulut ke mulut bisa saja berubah dari orang ke orang, ini akan membuat anggota PKH menjadi bingung dan ragu dalam menerima informasi tersebut. Sudah 5 tahun lebih program PKH berjalan di Nagari Lagan Hilir seharusnya pendamping menetapkan jadwal kapan dan dimana akan dilaksanakan pertemuan dengan peserta $\mathrm{PKH}$, sehingga peserta PKH tidak bingung kapan dana bantuan akan dicairkan.

\section{Jumlah Bantuan Tidak Sesuai}

Berdasarkan hasil penelitian menunjukkan bahwa batuan yang diberikan tidak sesuai dengan yang dianggarkan dan tidak menentunya 
jumlah bantuan yang diterima. Bahwa jumlah bantuan yang mereka terima berbeda, itu dikarenakan jumlah tanggungan keluarga yang berbedabeda pula, yang mana semakin banyak tanggungan dalam sebuah keluarga, maka banyak pula jumlah bantuan yang mereka terima, tanggungan yang dimaksud di sini adalah mulai dari anak belita sampai pada anak yang Sekolah Menegah Pertama. Namun jika dilihat skenario jumlah bantuan PKH terlihat sedikit berbeda antara jumlah bantuan yang diberikan dengan jumlah bantuan yang dianggarkan pemerintah.

\section{KESIMPULAN}

Berdasarkan hasil penelitian maka dapat disimpulkan bahwa tujuan Program Keluarga Harapan di Nagari Lagan Hilir Punggasan sudah tercapai jika dilihat dari segi bidang pendidikan dan kesehatan. Jika dilihat di bidang pendidikan minat anak-anak RTSM sudah tinggi untuk sekolah karena pakaian dan semua perlengkapan sekolah sudah memadai jika dibandingkan dengan tahun-tahun lalu yang belum mendapat PKH. Dan juga dilihat dibidang kesehatan ibu rumah tangga miskin sudah sering membawa anaknya untuk berobat ke Puskesmas dan belita tidak lagi kekurangan gizi, ini terungkap dari data primer yang peneliti dapatkan dari petugas Puskesmas.

Dalam penentuan sasaran PKH di Nagari Lagan Hilir Punggasan masih dianggap belum tepat sasaran, karena masih ditemukan di lapangan masyarakat yang dikategorikan kedalam ekonomi menegah ke atas yang mendapat bantuan, ini terungkap ketika peneliti melakukan pengamatan ke rumah peserta PKH. Dana bantuan PKH bagi RTSM sudah meringankan beban pengeluaran, namun RTSM masih menganggap belum cukup, mereka mengungkapkan bahwa perlengkapan pendidikan anak-anaknya semua mahal dan tidak mencukupi dengan bantuan yang mereka terima. Mereka hanya berharap pada bantuan pemerintah dan tidak adanya semangat kerja untuk merubah nasibnya sendiri. Berdasarkan beberapa hal di atas maka untuk tujuan penelitian dapat disimpulkan secara umum bahwa Program Keluarga Harapan di Nagari Lagan Hilir Punggasan sudah efektif jika dilihat dari tujuan program tersebut, tujuan dari program tersebut adalah meningkatakan taraf pendidikan anakanak RTSM dan meningkatkan akses pelayanan pendidikan dan kesehatan bagi anak-anak RTSM.

Khusus untuk penetapan sasaran penerima bantuan PKH bagi RTSM di Nagari Lagan Hilir Punggasan belum bisa dikatakan efektif. Hal ini dikarenakan dalam penentuan sasaran PKH belum tepat sasaran meskipun telah tepat tujuan. Ketidaktepatan sasaran ini disebabkan karena masih ada ditemukan di lapangan masyarakat yang dikategorikan ekonomi menegah ke atas mendapat bantuan PKH, penentuan sasaran tidak hanya melihat kondisi ekonomi yang tidak mampu, namun melihat adanya hubungan antara kader yang mendata dengan masyarakat setempat. Jadi pelaksanaan Program belum terlaksana dengan baik, ini dikarenakan kurangnya pengawasan dari pemerintah.

\section{DAFTAR PUSTAKA}

Anggraini, M. (2008). Perilaku Anggota Rumah Tangga Miskin Dalam Memanfaatkan Bantuan Langsung Tunai Program Kompensasi Pengurangan Subsidi-Bahan Bakar Minyak (BLT PKPS-BBM). Universitas Negeri Padang, Padang. Gusnaidi. (1998). Pemberdayaan Masyarakat Miskin Melalui Program Inpres Desa Tertinggal (IDT): Kasus Pelaksanaan Program IDT Tahap I (tahun Anggaran 1994-1995) di 
Desa Aur Begalung Kecamatan Bayang Kabupaten Pesisir Selatan. Universitas Andalas, Padang.

Hastuti. (2006). Kajian Cepat Pelaksanaan Subsidi Lansung Tunai Tahun 2005 di Indonesia (Kasus di Lima Kabupaten/Kota). Padang: Universitas Andalas.

Parnamian, J. (2010). Efektivitas Komunikasi antara Rumah Tangga Sangat Miskin Penerima Bantuan Tunai dan Pendamping Program
Keluarga Harapan. Institut Pertanian Bogor, Bogor.

Simanjuntak, M. (2010). Faktor-Faktor yang Mempengaruhi Kesejahteraan Keluarga dan Prestasi Belajar Anak pada Keluarga Penerima Program Keluarga Harapan. Institut Pertanian Bogor, Bogor.

Suparlan, P. (1984). Kemiskinan di Perkotaan. Jakarta: Sinar Harapan dan Yayasan Obor Indonesia. 


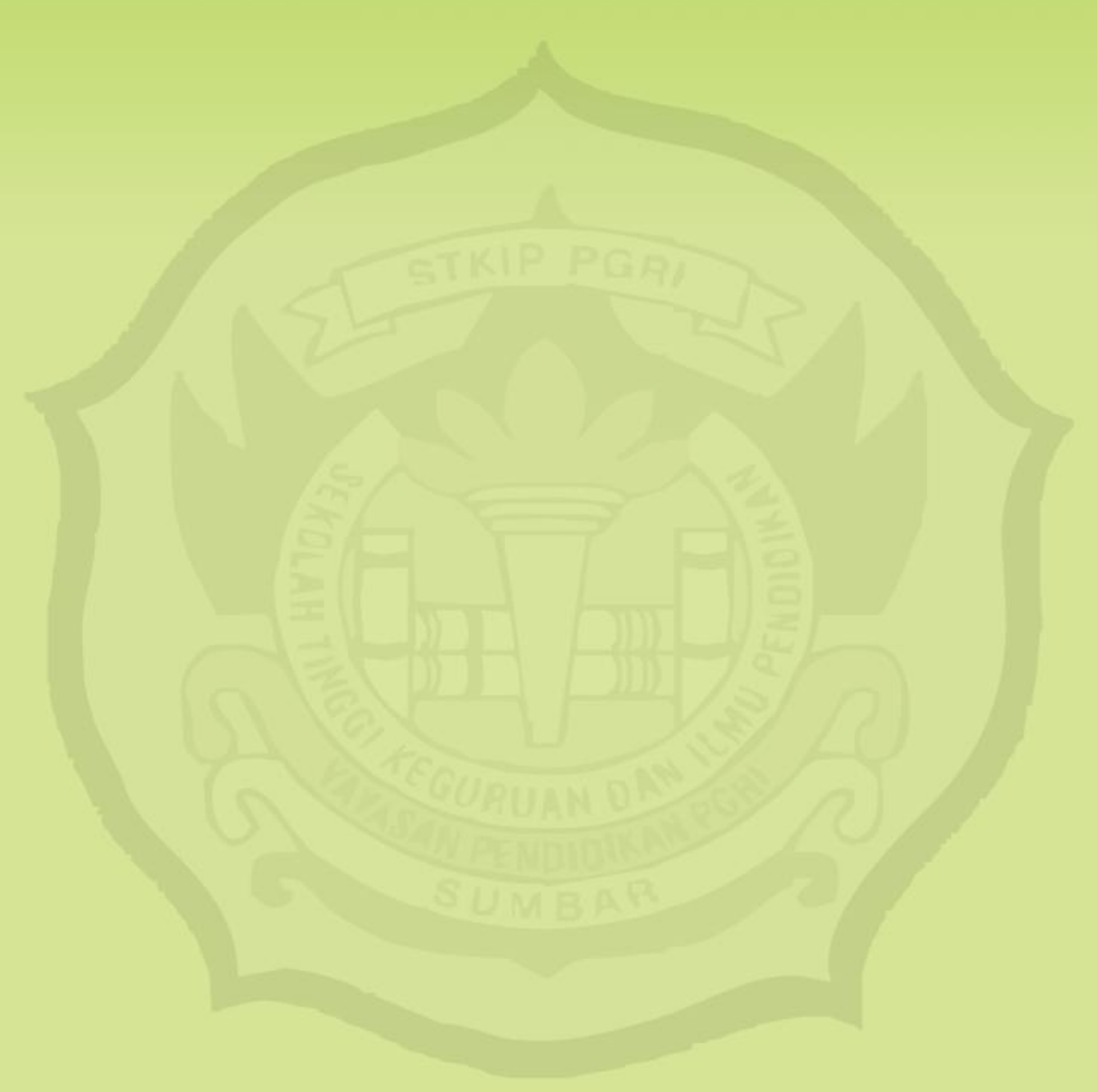

